\title{
Nete Nørgaard Kristensen \& Unni From: Kulturjournalistik. Journalistik om kultur. Frederiksberg: Samfundslitteratur. 2011.
}

\author{
Erik Svendsen
}

MedieKultur 2011, 51, 188-191

Published by SMID | Society of Media researchers In Denmark | www.smid.dk The online version of this text can be found open access at www.mediekultur.dk

Nete Nørgaard Kristensen og Unni Froms vægtige studie er paradoksalt nok lidt af et pionerarbejde. Der er skrevet mange afhandlinger om den politiske journalistik og andre felter inden for hard news, mens det skorter på større akademiske arbejder om human interest soft news, som (og det er paradokset) udgør stofområder, som flere læser med større lyst. Den materialistiske tankegang er indlysende rigtig: De politiske-økonomiske faktorer vejer tungere end den kulturelle overbygning. Journaliststandens hierarkisering af de forskellige samfundsmæssige delområder afspejler denne favorisering af den politiske offentlighed; der er mere status $i$ at tage sig af Christiansborg eller indenrigspolitik end i at rapportere fra den kulturelle offentlighed. På den anden side er borgernes orientering ikke determineret af de objektive økonomiske logikker, for nu at parafrasere tidligere tiders marxistiske begreber. I dag, i en posthabermask æra, er borgerne blevet forbrugere, og det betyder, at læserne (og seerne) foretrækker de underholdende aspekter, og derfor har kulturjournalistikken tiden for sig. Tilværelsen er meget mere end arbejde, politik, økonomi, EU, socialpolitik og de andre felter i hard news. De fleste læsere vil hellere orientere sig efter, hvor man kan få det sjovt, hvor fornøjelser og velvære er i højsædet.

Nørgaard Christensen og From er primært interesserede i at beskrive det journalistiske landskab og føre bevis for, at der notorisk er kommet flere kulturjournalistiske tekster i den danske presse, og at læserne bruger dem på ret forskellige måder, afhængig af hvilke forbrugere man spørger om mediereceptionsformerne. Desuden har bogen den force, at de to 
forfattere har interviewet en gruppe udøvende danske kulturjournalister, og på den konto kan redaktionelle principper og publicistiske ideer efterspores.

Fremstillingen falder i seks kapitler, og kompositionen er klassisk akademisk med en første del, der trækker teoretiske positioner op. I det første kapitel redegøres der for den sparsomme (nordiske og internationale) faglitteratur om emnet. Desuden berøres en række forhold, der senere elaboreres videre på, for eksempel det faktum at en stor del af kulturstoffet har skiftet karakter, sådan at servicejournalistikken vokser med både forbrugervejledninger en masse og livsstilsformidling i forskellige former (råd om bolig, mad, samliv osv.). I slipstrømmen på den udvikling kan afstanden mellem kulturindustrien, branchen og journalisten mindskes. Der spørges i en overskrift: "Kulturjournalisterne - kulturelt kyndige, medløbere eller medieprofessionelle?". Ansættelsesforhold angives, og der skelnes fortsat mellem akademisk uddannede fagspecialister, der tager sig af den æstetiske kritik, og den journalistisk faguddannede, som i vid udstrækning dækker stoffet via de journalistiske genrer som reportagen, nyhedsartiklen, som kritikerne ikke rører med en ildtang - eller som redaktionen ikke mener, de kan mestre. Spændingen mellem de to positioner angives med en historiserende udviklingstendens, som angiver, hvilken vej vinden blæser: "fra at kunne faget til at kunne mediet". Formidling og oplevelsesdimensionen er kommet i højsædet, hvorfor det med henvisning til Hjarvad hedder, at der er sket en magtforskydning i medierne "fra kultureliten til en ny kulturel overklasse af professionelle mediefolk, som forstår sig på og prioriterer modtagernes ønsker og interesser frem for finkultur og kanon" (p. 40).

Det andet kapitel uddyber disse udviklingstræk, eftersom der er en tendens i medieforskningen til at anskue udviklingen som en forfaldshistorie, akkurat som kanoniserede Habermas lancerede termen refeudalisering som dækkende for udviklingen i den borgerlige offentlighed. Heroverfor vil Nørgaard Christensen og From gerne plædere for det modsatte synspunkt, nemlig at afviklingen af den hegemoniske kritikerstand til fordel for læserne, der selv på nettets forskellige platforme giver deres mening til kende, rummer en demokratiseringsmulighed. Det er ikke den intellektuelle elite, der skal sætte dagsordenen for den kulturelle debat. Den borgerlige offentlighed erstattes af et kulturelt medborgerskab.

Kapitel tre er helliget de metodiske greb i den kvalitative og kvantitative undersøgelse, der er fundamentet for bogen. De to forfattere har dels foretaget en historisk anlagt kvantitativ analyse af kulturstof $\mathrm{i} / \mathrm{y}$ llands-Posten, Politiken, Ekstra Bladet og metroXpress fra 1890 og op til i dag, dels lavet kvalitative interviews med en gruppe kulturforbrugere, udvalgt efter kriterier, som der grundigt gøres rede for i kapitlet, ligesom hver en sten vendes, hvad angår validiteten og reliabiliteten i den mediehistorisk anlagte kvantitative analyse.

Kapitel fire redegør for kulturdækningen i disse repræsentativt valide kilder, og der spørges om, hvor meget, hvad, hvem, hvornår, hvordan og hvorfor kulturstoffet er blevet prioriteret, som analysen viser. Kapitel fem handler om forbrugernes tilgang, og der opereres med fire forskellige medieforbrugere, der rubriceres som henholdsvis det refleksive, bekræftende, søgende og selektive brugsmønster. De fire typer er i nogen grad afledt af en determinerende generationsforskel: De unge foretrækker de sociale medier som nyheds- 
kilde, også hvad angår kulturstof, og de bruger nettet selektivt. De ældre derimod udgør avisernes primærgruppe, og de er mere tilbøjelige til at opfatte avisen som en autoritativ kilde. Avisen - uanset hvilken man taler om - giver overblik over, hvad der sker, men den leverer også den baggrundsviden, som nettet sjældent leverer, og som brugerne heller ikke higer efter at indhente. Der skelnes yderligere mellem to former for brug, idet den rituelle brug kontrasteres med den situationelle brug. Den sidste repræsenteres af den unge bruger, som - når lejligheden byder sig - frekventerer de (tvær)mediale former, der er nærmest, eller som synes passende at bruge. Brugeren agerer i forhold til et mere eller mindre bevidst relevanssystem. Den første kategori er derimod den trofaste avislæser, der skal have dagens nyheder og uddybende betragtninger, og her synes indtagelsen af den daglige dosis at være en mellemting mellem pligt og lystlæsning. Avislæsningen giver kulturel kapital, in spe, mens den tilsyneladende selvstændige ageren på nettet giver en aura af frihed i pejlingen af, hvad man "føler for" i øjeblikket. Samstemmende om årsagen til, at brugeren går til kulturstoffet, hedder det, at "[...] såvel viden, overblik og opdatering, adspredelse og underholdning som oplevelse er væsentlige elementer i forklaringen af, hvorfor der læses" (p. 193).

Den refleksive forbruger anser sig selv for at være aktiv, engageret $i$ tidens konflikter, mens den anden er den loyale avislæser, som i snart mange år har sværget til en bestemt avis, der giver identitetsfølelse. Hvad der kommer først, er underordnet: om Politiken bekræfter opdaterede kulturradikale holdninger hos læserne, eller om læserne finder fodfæste i den offentlige debat qua deres avislæsning. Avisens holdninger og publicistiske linje matcher segmenternes livssyn. Denne apologetiske mekanisme kendetegner alle landets omnibusaviser, der næsten har delt markedet mellem sig, og for så vidt er der ikke de store forskelle mellem en Politiken-, Jyllands-Posten- eller Berlingske-læser. Heroverfor er den yngre medieforbruger mere søgende og styret af egne fornemmelser og trang til at være med på det nyeste. I egen indbildning er den søgende mediebruger uforudsigelig, samtidig med at man ønsker at pleje det sociale netværk og deltagelse i fællesskaber. Den selektive forbruger fravælger bevidst avisen, men er til gengæld en online nyhedsjunkie, der ikke skelner skarpt mellem formidlende genrer og kommercielle tekster om kulturprodukterne. Er det godt eller skidt, at brugerne er genreblinde? Den slags spørgsmål finder man ikke svar på i Kulturjournalistik. Den holder sig til akademisk neutralitet, om end man aner, at forfatterne hellere anskuer udviklingen som en bevægelse hen imod et kulturelt medborgerskab frem for en kritikkens deroute.

Det sidste kapitel redegør for de redaktionelle prioriteringer på de tre omnibusaviser, og en oplagt pointe er, at kulturstoffet i vid udstrækning (høj)profilerer den konkrete avis. Det er i den journalistiske vinkling og forvaltning af kritikken, at læserne finder sig til rette. Kultur er også politik og økonomi. Kulturstoffets udbredelse og dets former er også et moderne danmarksportræt.

Jeg har brugt en lille del af bogen i min egen undervisning i kulturjournalistik, og den fungerer fint. Bogens teser er valide, men også forsigtige, og jeg vil ikke mene, at bogen er indiskutabel. Den kalder flere gange på indsigelse. Eller man kunne sige, at den kalder på mere forskning i området. 
Lad mig afslutningsvis give et par eksempler på problemstillinger, der bør dvæles mere ved: Det er påfaldende, hvordan det er modne kvinder, som på læsersiden bærer kulturstoffet. Det skæve mønster kender vi fra en række andre samfundsmæssige forhold: Spørgsmålet er, hvordan medierne formelt og indholdsmæssigt kan rette op på ubalancen. Den klare segmentering, der præger landets aviser, må sammentænkes med en genpolitisering af presseoffentligheden; en proces, der ikke mindst inden for de seneste ti år har taget fart. Set i det perspektiv er omnibusavisen ved at være en truet race.

Endelig er der den overordnede diskussion om den komplekse udvikling, der både implicerer mere demokrati, øget segmentering og postmoderne kritikdecimering. Hvordan skal man som forsker og borger forholde sig til en række underspørgsmål, som hvordan man skal udlægge forskydningen fra "public man" til "private man", bevægelsen fra borger til forbruger? Hvordan skal man tackle udbredelsen af de sociale medier (til dels på bekostning af $\mathrm{tv}$ og aviser) og afviklingen af kritikken som hegemonisk udtryk? Hvad skal man mene om den manglende genrebevidsthed hos mange brugere, som ikke differentierer mellem redaktionelt stof og lanceringsjournalistik? Er det underordnet? Nej, det er i mine øjne en skræmmende tendens og vidner om alt andet end forbrugerens frihed.

Erik Svendsen

Lektor

Institut for Kultur og Identitet

Roskilde Universitet

evs@ruc.dk 